\title{
sciendo EVOLUTION OF THE EXTRUDER SCREW-DISK PLASTICIZING SYSTEM CONSTRUCTION
}

DOI 10.2478/ntpe-2018-0067

\author{
Assoc. Prof. Tomasz Rydzkowski \\ University of Warmia and Mazury \\ in Olsztyn, Poland \\ Assoc. Prof. Iwona Michalska-Pożoga \\ Koszalin University of Technology, Poland \\ PhD. Marcin Szczepanek \\ Maritime University of Szczecin, Poland \\ PhD. Vijay Kumar Thakur \\ Cranfiled University, Cranfield, United Kingdom
}

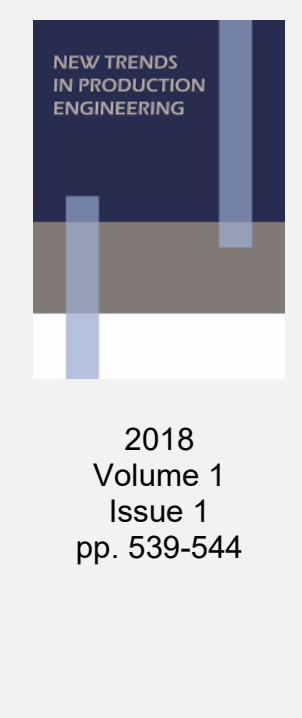

\begin{abstract}
The search for new polymer processing ways has become necessary due to the rapidly growing technology and market needs. The time of manufacturing products, as well as the impact of process parameters and the design itself on the properties of materials have become very important. Therefore, the creation of assumptions allowing the construction of a compact device whose construction will allow, for example, high process efficiency at low screw rotational speeds or a high degree of material homogenisation, is expected by the market. However, this requires the design of new or continuous modifications and improvements to existing structures.
\end{abstract}

Keywords: processing of polymer materials and composites, screw-disk extruder, single-cone plasticizing system, double-cone plasticizing system, compact design

\section{INTRODUCTION}

Screw plasticization is widely used both in extruders and injection molding machines (eg. Sikora 2008). In the world, extrusion of polymer materials is very commonly carried out on classical, well-known and thoroughly examined structures of plasticizing systems, namely: single-screw, double-screw, co-rotating and counter-rotating screws, screws equipped with shearing, mixing and shearing elements (eg. Bieliński, 1992; Pahl, 1993; Sikora 1993; Sikora 2009; Stasiek 1981; Zawistowski et al., 1999;).

Currently, new unconventional methods for plastics processing are being sought. One of them is extrusion with a screw-disk plasticizing system. The idea of the extruders with a screw-disk plasticizing system operation was to connect the disk zone with the screw zone. In this connection, the screw zone acted as a pre-plastification zone for the plastic, and above all, generated a sufficiently high pressure. In the disc area complete plasticization, homogenization and further compression of the plastic were to take place. The combination of these two zones created the possibility of obtaining high extrusion pressure and a high degree of homogenization. The first mention of the screw-disk construction of the extruder was published in the late sixties and in the seventies. The first operating of this type construction described was an extruder with a linear arrangement of the plasticizing system, characterized by the fact that a screw was installed before and after the disc. In this system, the first screw, placed before the disk, served as the feeder of the material, while the second screw (located after the disk) produced pressure, allowing the material to be pushed out of the extruder. The disc in this construction acted as a plasticizing element (Łukacz et al., 1981; Sikora, 1993, 2002). Another extruder is a construction with a screw-disk type with angular flow arrangement. In this construction there were also two screws and a disc. The role of the screw and disc was the same as in the construction described above. However, in this design, the plastic feed screw was located at an angle to the disk. Another construction, the closest to the currently existing extruders, is a screw-disk system equipped with one screw (screw placed 
before the disk under the container) and a disk. In the case of this construction, the screw was responsible for the transport of the material, for its initial plasticization and pressure creation, while the disk served as a homogenizing material. In this system, three zones were distinguished: in the screw part - the feeding and transformation zone, in the disk part - the homogenization zone (Łukacz et al., 1981). A common feature of all the above described structures was that the diameter of the disc was larger than the diameter of the screw (Kocherov et al., 1973; Zawporodnopo, 1976; Łukacz et al., 1981; Sikora, 1993, 2002).

\section{SINGLE-CONE PLASTICIZING SYSTEM OF SCREW-DISC EXTRUDER}

A new, experimental design combining the screw and disc zone was developed in 1995 by two collaborating teams of scientists: a team from the Koszalin University of Technology and a team from the Lublin University of Technology. It was created as a result of the theoretical analysis of J. Diakun (Diakun, 1991).

Research work led to the construction of an experimental screw-disk extruder (utility model No. RWU 64229) (Diakun and Sikora, 2009). It is an original design solution, based on the performed optimization and simulation calculations (Diakun et al., 1995). Initially, the plasticizing system for extruder for high-molecular plastics according to Polish patent No. 150 688 (Diakun and Bil, 1990) was supposed to have a material outlet opening with a diameter much smaller than the diameter of the cylindrical body, and a flat gap of the shield zone was created between the frontal plane of the body and the head of the screw (Fig. 1).

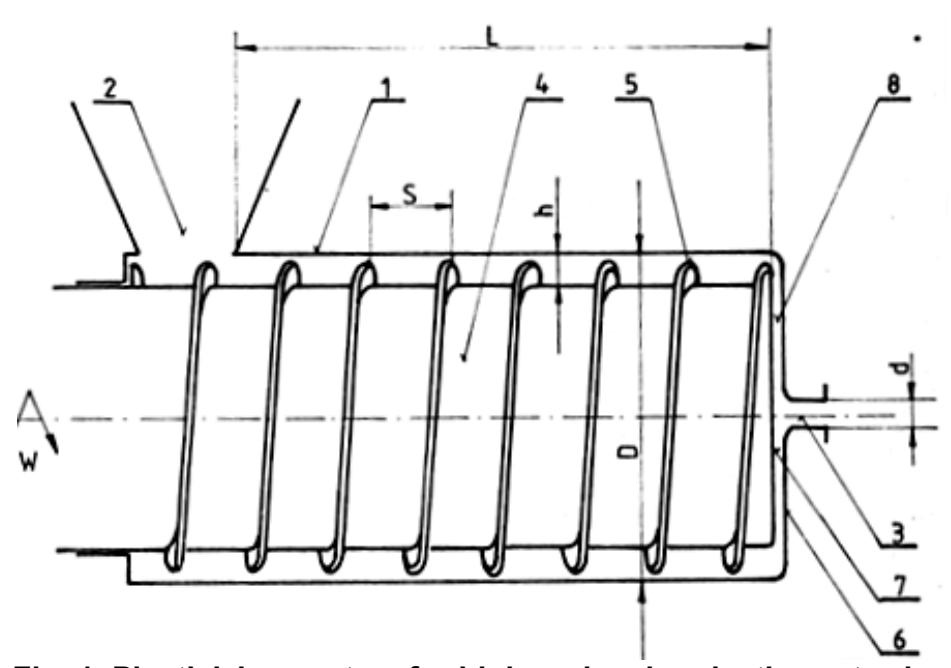

Fig. 1. Plasticizing system for high-molecular plastics extruder:

1 - body, 2 - hopper, 3 - material discharge opening, 4 - screw, 5 - screw, 6 - face plate,

7 - screw face, 8 - gap, D - screw diameter, s - pitch, h - coil height, L - screw length Source: (Diakun and Bil, 1990 - patent 150688)

Next, the extruder disk zone was modified, where the extruder disc zone has a conical gap/chink with a large obtuse angle and a constant inclination, from the outside diameter to the diameter of the nozzle opening (Polish Patent Application No. 349227). In the new construction (Fig. 2), the plasticizing system is equipped with a short screw $(L=2 D)$ with a large diameter $D=130 \mathrm{~mm}$ placed in a fixed, grooved cylinder. The linear, peripheral speed of the screw is in the range from 0.08 to $0.27 \mathrm{~m} / \mathrm{s}$. Such a screw construction enables the construction of a small compact extruder with comparable performance as classic extruders $(L=25 D)$. 

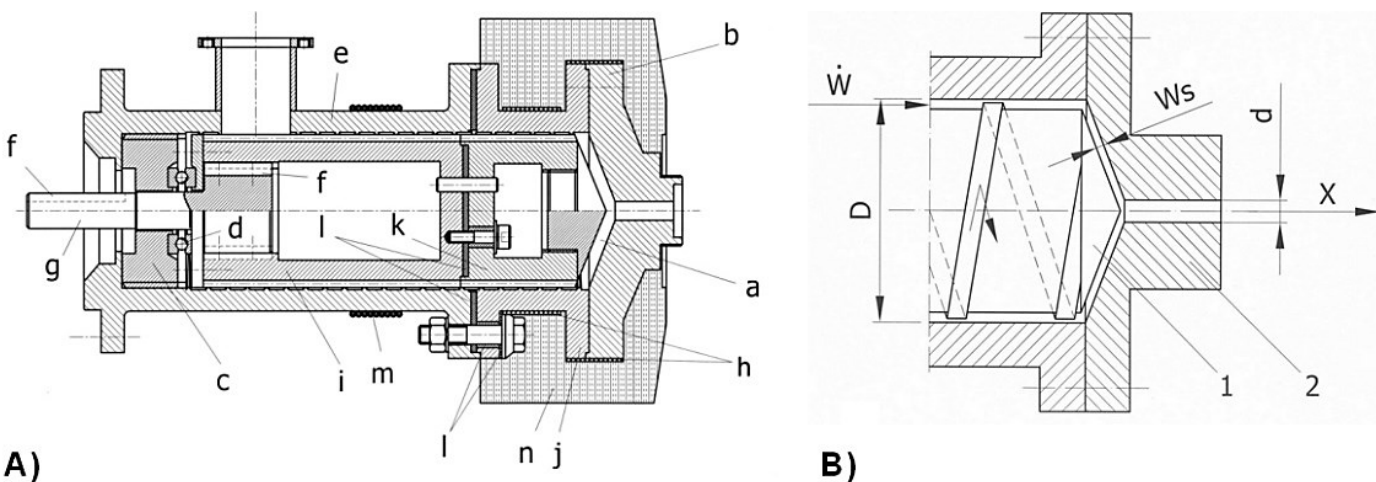

B)

Fig. 2. A) Cross-section of the plasticizing system of a screw-disk extruder:

a) disc zone, b) cylinder cover (stationary disc), c) thrust bearing of thrust bearing,

d) thrust bearing, e) cold part of cylinder, f) groove, $g$ ) drive shaft, $h$ ) radiators,

i) cold part of the screw, j) hot part of the cylinder, k) hot part of the screw,

I) thermal insulation layer, $m$ ) cooling band, $n$ ) thermal insulation;

B) Cross-section of the shield zone:

1 - rotating disc, 2 - cylinder cover (stationary disc), Ws - gap, W - flow rate, d - nozzle diameter, $X$ - material flow direction, $D$ - disc diameter

Source: (Michalska-Pożoga and Jakubowski, 2012; Michalska-Pożoga, 2017)

The face of the screw is a movable disc while the extruder housing - cylinder cover is a stationary disk. A disc space gap is created between the movable and immovable targets (Fig. 2B). The screw is equipped with a mechanism that allows the gap to be set without dismantling the structure (Fig. 3).

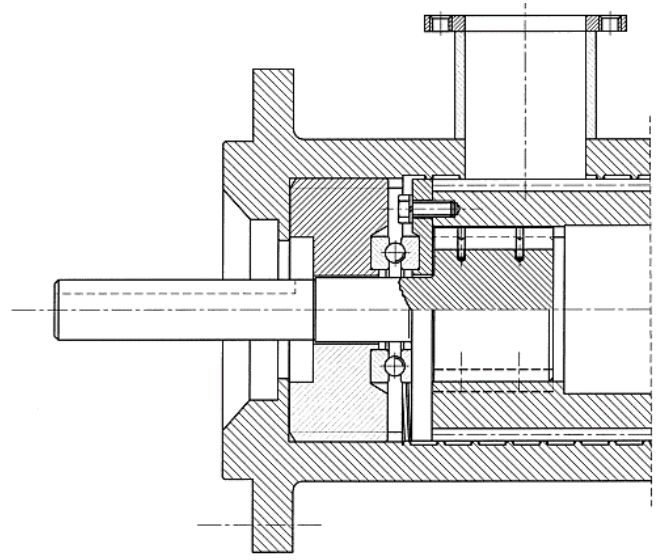

Fig. 3. Scheme of the mechanism allowing to set the gap size of the shield zone Source: (Rydzkowski and Radomski, 2008) of the screw-disk extruder.

Due to the occurrence and the possibility of adjusting the gap between the front of the screw (movable disc) and the cylinder cover (stationary disc), it can influence the process of plasticizing and homogenization of polymer materials (Rydzkowski and Diakun, 2005; Rydzkowski and Radomski, 2008). In the disc zone, the viscous material in the form of a liquid of high viscosity is homogenised in the course of the flow from the outer diameter of the disc $D$ to the outlet of the nozzle $d$ in the disk gap. The initial plasticizing step takes place in the feeding zone, and the second stage of plasticization and homogenization is carried out in the conical zone of the screw, the inclination angle of which is equal to $\alpha=133^{\circ}$.

The screw-disk extruder with a single-cone plasticizing system was tested and described in the years 1990 - 2016 by a team of scientists from the Koszalin University of Technology. The analyzes concerned the influence of the single-disk disc zone on the properties of the obtained extrudate (eg, Michalska-Pożoga and Diakun, 2014; Michalska-Pożoga, 2014), its suitability for mixing various materials (eg Radomski, 2002, 2003, 2005; Rydzkowski and Radomski 2008; Rydzkowski, 2011), and suitability for recycling and creation of polymer-wood composites (WPC - wood plastic composites) (Rydzkowski and Radomski, 2008; Rydzkowski 
and Michalska-Pożoga, 2014; Michalska-Pożoga and Rydzkowski, 2016; Michalska-Pożoga, 2017). Numerous numerical analyzes were also carried out regarding the conditions prevailing in the extruder disc zone, and the trajectories of the plastic particle motion and their influence on the conformational structure of polymer macromolecules (eg, Michalska-Pożoga and Diakun, 2004; Michalska-Pożoga and Jakubowski, 2012) were determined.

A long-term analysis of the research of this construction allowed to state that the unique phenomena occurring in the screw-disk plasticizing system creates the possibility to process polymer plastics in a different way than in classical devices.

The nature of the plastic particles moving in the disk zone of the screw-disk extruder (occurrence of the speed gradient) may cause the development of polymer chains and structure ordering, which should affect the increase in the degree of crystallinity of the extrudate and the possibility of increasing both strength and impact resistance. It has been observed that the influence of the shield zone changes depending on the set gap value in this zone (Ws). This is due to the shear stresses and shear rate arising in this area. The low value of the disk gap results in the conditions of intensive shear-mixing action, whereas the high value of the gap induces a gentle, long-lasting mixing effect (Michalska-Pożoga, 2017). Thanks to this, we can design the properties of the obtained extrudates in a conscious way.

However, in addition to the positive phenomena occurring in the disc zone under investigation, simulation and experimental tests have also shown an adverse effect in the disc zone. The problem observed was that the development of polymer chains occurred only in the zone of the larger diameter of the cone. However, as you approach the central zone (smaller diameter of the cone), the next unfavorable effect of the partial re-shaping of polymer chains has prompted researchers from the Koszalin University of Technology to conduct further research in order to overcome this negative effect.

\section{A NEW DOUBLE-CONE CONSTRUCTION OF SCREW-DISC EXTRUDER PLASTICIZING SYSTEM}

The solution to the problem of the collapse of polymer chains was proposed by I. MichalskaPożoga in her scientific works. On the basis of the analyzed results of simulation-experimental research, as well as the identification of conditions prevailing in the disk gap of the screw-disk extruder, it was found that the unfavorable effect of the polymer chain's scaling can be compensated by introducing a modification of the front part of the screw. In place of the singlecone design of the disk zone, its original double-cone structure was proposed (Fig. 4).

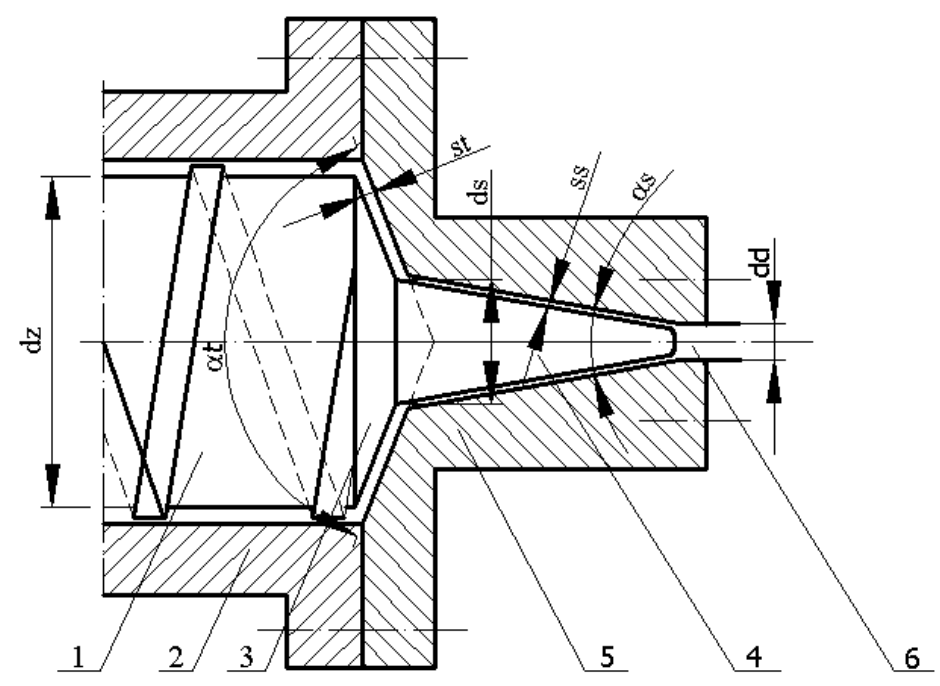

Fig. 4. A diagram of double-conical disk zone of a screw-disk extruder:

1 - rotary screw, 2 - fixed cylinder, 3 - first conical surface with obtuse angle $\alpha$, 4 - second conical surface with an acute cone angle as, 5 - cylinder cover, 6 - nozzle, Source: (Patent 210138, 2011) ds - slotted cone diameter, dz - outer diameter of screw 
In this construction, the disc zone consists of: an obtuse cone zone with a base diameter equal to the diameter of the screw ( 3 in Fig. 4) and a slender cone zone - going into the discharge nozzle channel (4 in Fig. 4). Such a structural arrangement divides the disc zone into two conical subzones with different opening angles (opening angle of the first cone - at, opening angle of the first cone - as). After many analyzes, it was found that in the most advantageous solution the obtuse cone zone should have an inclination angle greater than $140^{\circ}$, and the slender cone zone should have an inclination at an angle smaller than $50^{\circ}$. The largest diameter of the slender cone zone is from $1 / 4$ to $1 / 2$ of the outer diameter of the screw.According to numerical analyzes, the new disc zone design may have a beneficial effect on the process of extrusion of the polymer material as well as composites (Michalska-Pożoga and Jakubowski, 2015). The new construction will allow to obtain:

- materials with good homogeneity of the material at low shear rate (with a large distance between two cones of the plasticizing and homogenizing zone);

- high homogeneity of materials of plastic mixtures, which is important in particular for the extrusion of recycled materials and their mixtures, preparation of color concentrates or polymer compositions with fibrous or hybrid fillers during extrusion (with a small fracture value of the plasticizing-homogenizing zone, and consequently obtaining, strictly adjustable, high shear rate value),

- a higher degree of ordering at the level of the supramolecular structure of the polymer.

An extruder equipped with such a disc zone structure could have wider application in plastics processing than the previous construction, in particular for the creation of polymeric blends, polymer compositions with fillers, as well as for the production of polymer composites and in recycling. The proposed construction obtained patent protection in 2011 (Patent PL 210138).

\section{SUMMARY}

Analyzing the market under the account of new technologies concerning extrusion processes of polymer materials, there has been no hitherto used in industrial constructions, extruders with a double-cone plasticizing and homogenizing zone. A novelty in this design is a completely different concept of the structural solution of the plastifying and homogenizing zone. The use of such a construction will allow to obtain a material with improved functional properties: high strength, increased impact strength, a higher degree of crystallinity, higher barrier properties.

\section{REFERENCES}

Bieliński, M. (1992). Badanie wybranych właściwości polietylenu wtórnego. Polimery, 8, pp. 364-370.

Diakun, J. (1991). Podstawy uaktywnienia strefy zasilania w konstrukcji strefy ślimakowej, Monografia, Wydział Mechaniczny nr 30. Wydawnictwo Uczelniane Wyższej Szkoły Inżynierskiej w Koszalinie, Koszalin.

Diakun, J. and Bil, T. (1990). Układ uplastyczniający wytłaczarki do tworzyw wielkocząsteczkowych. Patent PL 150688.

Diakun, J., Bil, T. and Kiczkowiak, T. (1995). Simulationsberechnungen für Erwärmungsverlauf. Kunststoffberater, 7-8, pp. 45-47.

Diakun, J. and Michalska-Pożoga, I. (2003). Symulacja obliczeniowa ekstremalnych warunków i miejsc degradacji PE w strefie tarczowej wytłaczarki, Zeszyty Naukowe Politechniki Krakowskiej Kraków, Wydawnictwo Politechniki Krakowskiej, s. 131-136.

Diakun, J. and Michalska-Pożoga, I. (2011). Strefa tarczowa wytłaczarki do tworzyw polimerowych. Patent PL 210138.

Diakun, J. and Sikora, R. (2009). Wytłaczarka do tworzyw polimerowych. Wzór użytkowy nr RWU 64229.

Diakun, J. and Sikora, R. (2001) Wytłaczarka do tworzyw polimerowych. Zgłoszenie patentowe 349227.

Kocherov, V.L., Lukach, J.E., Sporyagin, E.A. and Vinogradov, G.V. (1973). Flow of polymer melts in a disk - type extruder and in rotation devices of the "cone - plate" and "plate plate" type. Polymer Engineering Science, 13, pp. 194-201. 
Łukacz, J.E., Petuchow, A.D. and Senatos, W.A. (1981). Oborudowanie dla proizwodstwa polimernych plenok, Maszinostrojenije, Moskwa.

Michalska-Pożoga, I. (2017). Studium efektywnego wytłaczania kompozytów polimerowych z wykorzystaniem ślimakowo-tarczowego układu uplastyczniającego. Monografia nr 319, Wydawnictwo Politechniki Koszalińskiej, Koszalin.

Michalska-Pożoga, I. and Diakun, J. (2014). The influence of the disc zone of a screw-disc extruder on the structure and properties of low-density polyethylene (PE-LD) extrudate. Polimery, 59(11-12), pp. 845-850 DOI: dx.doi.org/10.14314/polimer.2014.845.

Michalska-Pożoga, I. and Jakubowski, M. (2012). Analiza CFD ruchu cząstki i charakteru przepływu tworzywa polimerowego w strefie tarczowej wytłaczarki ślimakowo-tarczowej. Przemysł Chemiczny, 91, 9, pp. 1808-1812.

Michalska-Pożoga, I. and Jakubowski, M. (2015). Analiza CFD przepływu tworzywa polimerowego w dwustożkowej strefie uplastyczniająco-homogenizującej wytłaczarki ślimakowo-tarczowej. Przemysł Chemiczny, 94(12), pp. 2105-2111 DOI: 10.15199/62.2015.12.3.

Michalska-Pożoga, I. and Rydzkowski, T. (2016). The effect of extrusion conditions for a screw-disk plasticizing system on the mechanical properties of polypropylene/wood composites (WPC). Polimery, 3, pp. 47-55 DOI: dx.doi.org/10.14314/polimery.2016.202.

Radomski, G. (2005). Porównanie ujednorodniania przy wytłaczaniu w wytłaczarce ślimakowej i ślimakowo - tarczowej. Polimery, 50, pp. 374-378.

Radomski, G. (2002). Wizyjna metoda oceny rozprowadzenia składnika w kanale ślimaka wytłaczarki. Inżynieria i Aparatura Chemiczna, 41(4s), pp. 109-110. 123.

Radomski, G. (2003). Mechanizm ujednorodniania tworzywa w strefie tarczowej wytłaczarki. Inżynieria i Aparatura Chemiczna, 42(3s), pp. 132-133.

Rydzkowski, T. (2011). Właściwości mieszanin recyklatów otrzymywanych w procesie wytłaczania ślimakowo-tarczowego. Polimery, 54, pp. 135-139.

Rydzkowski, T. and Diakun, J. (2005). Proc. 21 Annual Meeting of Polymer Processing Society, Niemcy, Lipsk.

Rydzkowski, T. and Radomski, G. (2008). Mixing ratios obtained using screw-disc type and screw extruders; selected properties of regranulate and the original material mixtures. Plastic, Rubber and Composites: Macromolecular Engineering, 37(8), pp. 376-380. Doi: $10.1179 / 174328908 \times 356473$.

Pahl, M.H. (1993). Homogenisieren in Schneckenmaschinen. Mischen von Kunststoff und Kautschukprodukten. VDI VERLAG Düsseldorf, pp. 241-296.

Rydzkowski ,T. and Michalska-Pożoga, I. (2014). A study on polymer particle flow in a disk zone of a screw-disk extruder. Chemical and Process Engineering, 35, pp. 121-135.

Sikora, R. (1993). Przetwórstwo tworzyw wielkocząsteczkowych, Wydawnictwo Edukacyjne ŻAK, Warszawa.

Sikora, R. (2002). Leksykon Naukowo-techniczny. Wprowadzenie do Przetwórstwo tworzyw polimerowych, Lublin, Wadim Plast sp. j.

Stasiek, J. (1981). Współczesne kierunki rozwoju w konstrukcji układów uplastyczniających wytłaczarek jednoślimakowych do polietylenu. Polimery, 1, pp. 27-32.

Sikora, J.W. (2008). Selected Problems of Polymer Extrusion. Politechnika Lubelska, Wydawnictwo Naukowe WNGB, Lublin.

Sikora, J.W. (2009). Screw extrusion. In: T. Sabu i W. Yang, eg., Advances in Polymer Processing. Woodhead Publishing Limited, Oxford Cambridge; New Delhi.

Zawistowski, H. (1999). Wytłaczanie tworzyw sztucznych. Wydawnictwo poradników i książek technicznych Plastech. Warszawa.

Zawporodnopo, W.K., (red.) (1976) Oborudowanie dla pierierabotki płastmass. Izdatielstwo Maszinostrojenie, Moskwa. 